\title{
THE IMPACT OF SOCIAL MEDIA ON SALES PROMOTION IN ENTERTAINMENT COMPANIES
}

\author{
Dalia Štreimikienë ${ }^{1}$, Asta Mikalauskiené ${ }^{2}$, Urtė Sturiené $\dot{e}^{3}$ \\ Grigorios L. Kyriakopoulos ${ }^{4}$
}

\begin{abstract}
Vilnius University, Kaunas Faculty, Lithuania, ORCID: 0000-0002-3247-9912, dalia.streimikiene@knf.vu.It; Vilnius University, Kaunas Faculty, Lithuania, ORCID: 0000-0002-4301-2058, asta.mikalauskiene@knf.vu.It; Vilnius University, Kaunas Faculty, Lithuania, urte.brazdzionyte@gmail.com;

National Technical University of Athens, School of Electrical and Computer Engineering, Electric Power Division, Photometry Laboratory, Greece, ORCID: 0000-0003-4875-8534,gregkyr@chemeng.ntua.gr.
\end{abstract}

\begin{abstract}
Social networks including various social media are one of the main online marketing tools that help to achieve marketing aims of the company. Most of social media overlap and have more than one characteristic, aim or purpose. It should be noted that interaction, user-friendliness, openness, freedom and real time are the main features of all social media. When starting to discuss sales promotion of a company on social media, the concept of social commerce becomes inevitable. Taking into account current trend of expansion of internet marketing because it unites the biggest number of users and has the means to implement different aims of the companies, it is necessary explore the impact of social media on sales growth in specific sectors. The paper analyses the impact of social media for sales promotion in entertainment sector. During the quantitative research, 385 respondents were surveyed. The questionnaire of the quantitative research has been prepared based on the marketing communication model for social media used by entertainment companies. The questionnaire included closed type of questions, most of them are provided in Likert scale. The empirical study found that elements (promotion of sales increase; brand strengthening), maintaining connections with present and potential company's clients that are used by the entertainment companies on social media help to promote sales with users' engagement. Regular communication of entertainment companies on social media has a positive impact on sales, because users tend to follow such type of accounts actively. The study emphasised the main elements to be applied by the entertainment companies using social media. Therefore, the regular communication and use of influencers are highly recommended for sales promotion of companies. It is also important to stress that companies are advised to communicate regularly, as regularity in communication is one of the most important drivers of sales promotion.
\end{abstract}

Keywords: Social media, internet marketing, sales, entertainment sector.

JEL Classification: L82, L86, M15.

APA Style Citation: Štreimikienè, D., Mikalauskienè, A., Sturienè, U., \& Kyriakopoulos, G. L. (2021). The Impact of Social Media on Sales Promotion in Entertainment Companies. E\&M Economics and Management, 24(2), 189-206. https://doi.org/10.15240/tul/001/2021-2-012

\section{Introduction}

Due to the improvement of technologies and increasing number of internet users, more companies choose social networks to promote sales of goods and services, increase recognition and visibility and communication with potential clients in real time online.
At the moment, internet marketing is considered one of the most powerful marketing tools, because it unites the biggest number of users and has the means to implement different aims of the companies. The quickly increased popularity of social networks and social commerce are considered the third 
revolution of communication that provides freedom for companies to communicate with target audience, regardless of place and time (Stoian et al., 2018; Pavlovaite \& Gresiene, 2019; Zhou et al., 2013; Zhang et al., 2020). Thus, the impact of internet and marketing tools, in a general sense, is a phenomenon that is highly significant in the business world and is developing quickly.

The development of marketing in every company is an important and relevant area that can increase recognition as well as the net profit. In the modern world, each business organisation has possibilities to reach marketing aims online. It should be noted that a particular social network or a combination of several of them at the same time could be significant when trying to reach the set aims. The elements of social networks that help to achieve the aims that are set by the company should not be disregarded as well. A lot of attention is provided to the definition and classification of social networks (Keenan et al., 2009; Mróz-Gorgoń \& Peszko, 2016), personal data protection on social platforms, of online word-of-mouth importance (Ajina, 2019; Ahmed et al., 2019; Onete et al., 2020; Gavurova et al., 2018); however, the promotion of sales by employing social networks has not been researched sufficiently, though some authors were analysing YouTube impact on youth purchase decision (Duffett et al., 2020; Yaman, 2018) or Generation $Z$ purchase preferences (Dabija et al., 2020). The paper determined the impact of social media for sales promotion in the entertainment sector, being structuring a literature review on social networks, followed by methods and data. Thereafter, the results of empirical study are presented and the main keyaspects of the analysis have been discussed and concluded, respectively.

\section{Theoretical Background and Hypotheses Development 1.1 Literature Review on Social Networks}

Social networks are one of the main online marketing tools that help to achieve marketing aims of the company. Internet marketing, as well called interactive marketing, is a subset of digital marketing. The main peculiarity of the internet marketing is that it requires a direct internet connection (Abud, 2019). It could be stated that social media marketing is the smallest unit of the processes: a part of electronic marketing $\rightarrow$ electronic commerce $\rightarrow$ e-business. The appearance of social networks is frequently identified with the creation of internet Web 2.0 technology. Social networks have been acknowledged as one of the most important platforms for brand communication due to interactive features that enable to participate, communicate and exchange knowledge (Knoll, 2016). Such scholars as Yu et al. (2019) state that brands advertise in social networks (such as Facebook, YouTube and others) as well as use services of bloggers and influencers, create and manage content.

Based on the scientific literature review, there can be found many various understandings of social networks. It has been noticed as well that the terms social media and social networks are frequently used as synonyms. Scientists do not have a unanimous opinion when and which term should be used. For example, Boyd and Ellison (2008) state that social networks are a part of social media and define the concept of social networks by determining 3 main possibilities for social network users: 1 ) create and add public or semi-public profile within a bound system; 2) articulate a list of other users with whom they share a connection; 3) analyse list of connections, allow access. These possibilities can differ depending on the social network. Evans (2008) as well state that social networks would not exist without social media. Social media is a much wider term, encompassing all technologies that enable users, brands to use social networks on computer, phone, tablet or other devices, to have more than one profile etc. and to achieve popularity of the content by using social media voting tools. The statement of Keenan et al. (2009) adds to this opinion: the aim of social networks is to transfer relations from reality into virtual social networks. One of the reasons why there are so many social networks and social media concepts and attempts to define them in various sources is the quick improvement of technologies and appearance of new social networks that add new components to scientific terms.

The analysis of the proposed social media definitions could be summarised with the idea proposed: the scope of social media can hardly be defined finally. Following Xie et al. (2012), the author claims that regardless of difficulties when defining the scope, all social media have 


\section{Fig. 1: The main zones of social media}

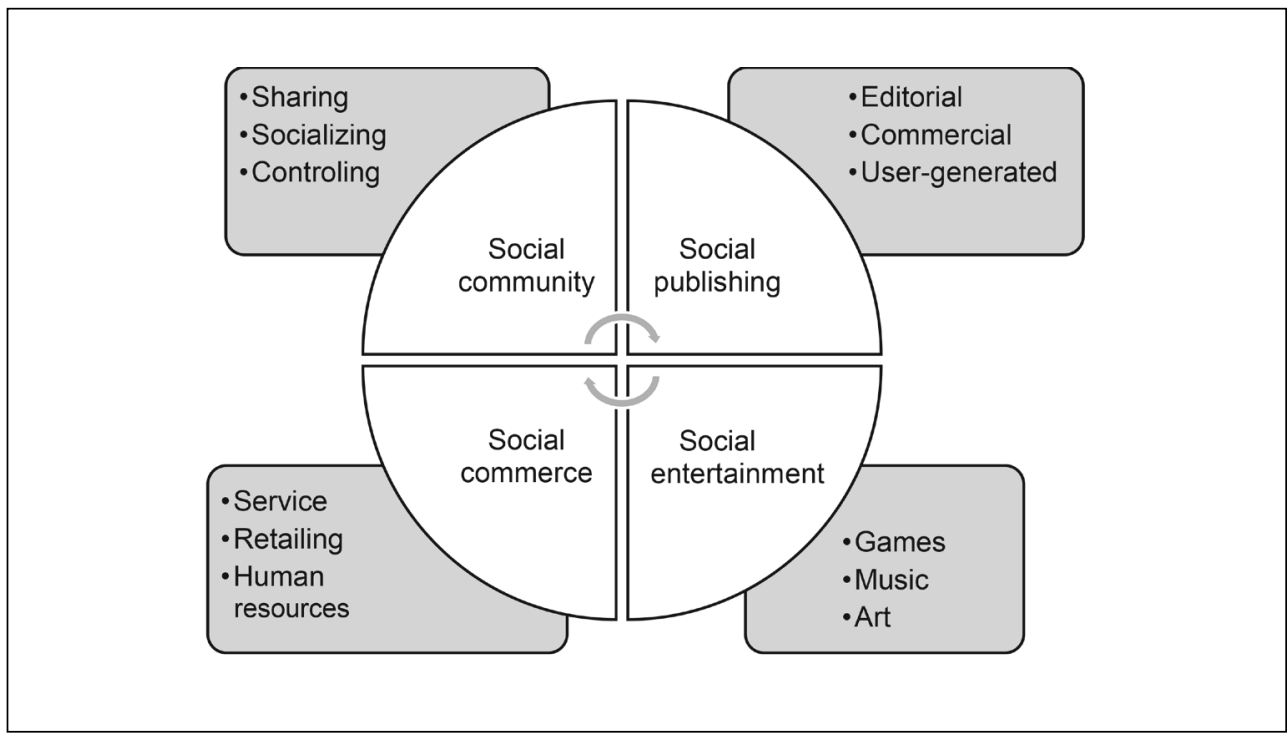

Source: own based on Tuten and Solomon (2018)

common features: all of them depend on virtual communication. Tuten and Solomon (2018) has grouped social media into zones based on social media working principles (Fig. 1). It should be mentioned as well that when dividing social media into zones, the audience assessed them from users and businesses perspectives.

Thus, as it can be seen in the Fig. 1, the first zone social community describes the channels of social media that focus on the relationships between users. Usually, in such type of social media, two-way as well as multiway communication is possible. Everyone in the community can have their own roles: from active participants to brand representatives, making commercial offers. The channels in the social community zone include forums, social networks gathering communities and chat software wikis. The second zone social publishing describes channels that help users to create interesting content: various texts, photo albums, videos etc, and share the created content with others. Content creators can be divided into 4 groups: 1 ) individual users; 2) independent professionals; 3) professional contributors representing brands; and 4) brands. Blogs, photos, videos, presentations, music and design sites belong to this social media zone. The third social media zone is social entertainment. These channels have been created to provide users with pleasure and enjoyment when playing games, listening to the music, watching videos. The main difference between social publishing and social entertainment channels is the perspective, i.e., in the first case, it is aimed to share knowledge and talents with the community; in the second case, it is done in order to entertain, have a good time. The fourth zone is social commerce. The channels of this zone enable users (individuals as well as brands) to sell, buy goods and services and include the third parties (opinion leaders) who can advertise goods and services on these channels. The channels that belong to this zone can be used as a platform for performing exchanges and marketing that have been mentioned or used only for connecting into other sites and e-shops. It should be noted that there are no strict lines between these social media zones. Some social networks can belong to more than one zone and have different characteristic, e.g., to unite social community and social entertainment in one channel.

Due to the increased popularity of social media, brands had to adapt and promote interactive sales in social media, offering to buy 
goods and services directly or redirecting to the online store. Thus, the main idea of social commerce to sellers is to create closer relations with clients, enriching the quality of relationships, increasing sales and encouraging loyalty. It should be noted that due to the technological possibilities and a variety of social media, there have appeared many different ways to make sales. Han et al. (2018) has made a list of social commerce types that are most frequently used by brands. It is as well clear that such a variety of ways to sell goods and services with the help of social media provides brands with advantages when seeking to achieve the set marketing goals more efficiently.

After reviewing scientific sources, it has been noticed that scientists stress the importance of social media strategy when promoting sales. Having analysed 66 scientific articles on the theme of social media strategy, Effing et al. (2015) distinguished the main elements of the strategy: 1) Target Audience; 2) Chanel Choice; 3) Goals; 4) Resources; 5) Policies; 6) Monitoring; and 7) Content Activities.

Casalo et al. (2018) analysed the impact of opinion formers otherwise called opinion leaders or influencers on social networks. It is stated that an influencer is an important source of advice and information for the users that want to buy goods or services. Usually, such practices are most common on social network
Instagram. In 2017, advertisers invested more than 1 billion dollars, i.e., they spend their money for advertising goods and services with the help of influencers. The authors have provided a theoretical model that illustrates the effect of the content created by opinion leaders on the users (see Fig. 2).

Thus, original, unique, qualitative and quantitative content that is created by an influencer can have a positive effect on the consumer's intentions to interact in a social network, recommend seen or heard information and follow the received advice that leads to buying a certain product or service. In other words, users believe and trust an influencer due to his/her content characteristics; therefore, a decision to buy goods and services is made easily. It should be noted, that usually the created content is related to fashion, beauty products, cosmetics etc. It should be stated that the content created by influencers on social media is one of possible strategies for sales promotion that companies working in beauty and fashion industries can apply.

According to Hudák et al. (2017), the development of internet in recent years has dramatically changed the business, i.e., gathered users into one network and made companies to look for ways to reach their target customers. The research on the use of internet and online tools that was conducted by Akhmetova et

\section{Fig. 2: Theoretical model of the effect of opinion leaders}

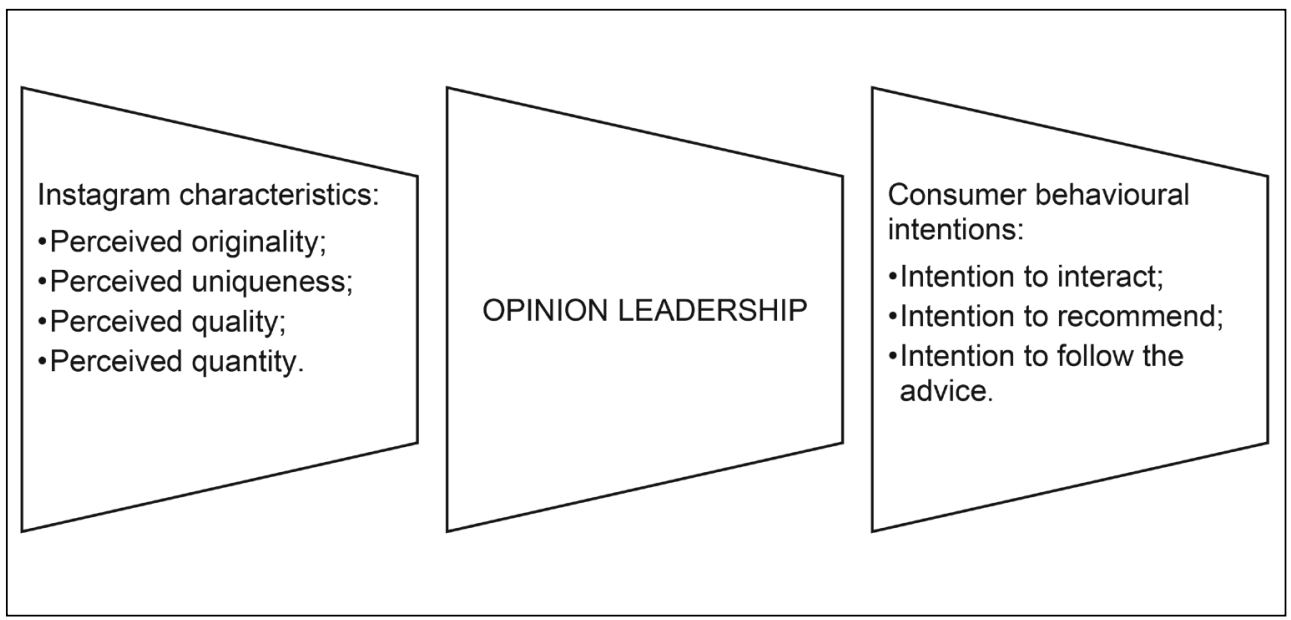


al. (2018) has revealed that different online marketing tools are used in these countries in comparison to the Western countries or Europe, but the usage of internet is quickly increasing. Besides, Stewart (2009) stated that marketing can have many different results in business; thus, thinking about marketing only as a means to achieve company's financial goals is incorrect. It is important to note that when trying to measure the effects of marketing tools, it should be related to financial metrics. In next section an integrated approach and thematic synthesis of the collected literature review has been developed.

\subsection{Integrated Approach and Thematic Synthesis of Literature Review}

The decisive role of social media to investigate the significance of SME's adoption to e-commerce processes has been evidenced (Abed et al., 2015). At this study the adoption of e-commerce by SMEs by using social media in Saudi Arabia it was reviewed. The prevailing research dimensions were classified and valued as follows: information and communications technology (ICT), e-commerce and businesses, consumerism association with e-commerce, SMEs and e-commerce in the light of social media engagement by SMEs in Saudi Arabia. In such an approach, literature gaps and further research directions were also comprehended (Abed et al., 2015).

The relationship between social media and e-commerce has been also linked to the social impact theory. In particular, it is important researchers to determine the influential role of social media toward the development of e-commerce, as well as to investigate how affectionate social media should prove to users' visit and purchase. From a methodological viewpoint, a survey and a structural equation's modeling indicated that social media a) interaction ties and b) commitment, they can positively affect normative and informational social influence. In turn, informational social influence in e-commerce is positively affecting customers' visit and purchase (Kwahk \& Ge, 2012).

In any research approach it is critical researchers to deep into profile of consumers, emerging needs, and digital specialtyprerequisites at this new digital era. In this context, a model being epitomized as "long tail market" had been introduced to describe the Hollywood affiliation to this new digital era in linking business models followed by American studios and the downloads of films or TV programs. These accelerated changes in the movie value chain can change the physiognomy of the entertainment industry and the business strategies, accordingly (Pardo, 2013).

At the relevant literature production the main fields of conceptualization on social media have been based on the Scopus database search at September 2020, unveiling the following four main categories: Internet marketing; Internet management; Business, sales and entertainment; E-commerce and brand. These results have been further classified in keyword domains, unveiling the following six scientific domains: Business, Management and Accounting; Economics, Econometrics and Finance; Computer Science; Social Sciences; Engineering; Arts and Humanities; Decision Sciences. These verbal responses were grouped and introduced an aggregated Tab. 1, in which each literature pair (social media field,

\begin{tabular}{|c|c|c|c|c|c|c|c|}
\hline $\begin{array}{l}\text { Aggregated p } \\
2010-2020\end{array}$ & ofile of "s & cial me & ia" conce & tualiza & on withir & he last & ecade, \\
\hline $\begin{array}{l}\text { Fields of "social media" } \\
\text { conceptualization }\end{array}$ & BMA & EEF & cs & SocSci & Eng & $\mathrm{AH}$ & DecSci \\
\hline Internet marketing & 4 & 3 & 2 & - & - & - & - \\
\hline Internet management & 3 & 1 & 2 & 3 & 2 & 1 & 1 \\
\hline $\begin{array}{l}\text { Business, sales and } \\
\text { entertainment }\end{array}$ & 6 & 4 & 1 & - & 2 & - & - \\
\hline E-commerce and brand & 8 & - & 12 & 3 & 6 & - & 4 \\
\hline Sub-total (out of $100 \%$ ) & $21(30 \%)$ & $8(12 \%)$ & $17(25 \%)$ & $6(9 \%)$ & $10(15 \%)$ & $1(2 \%)$ & $5(7 \%)$ \\
\hline
\end{tabular}


scientific domain) has been jointly presented and quantified, respectively. Acorpus of the most important studies' selected, it was represented in reverse chronological order of publication, while special consideration was taken that all selected studies to offer a pluralistic coverage and systematic overview of all key-aspects reflecting the collected literature production.

Based on the analysis performed above, it is noteworthy that social media are apparently influencing e-commerce and buying behaviours because of their capability to enhance customers' experience. Social media can support the conveyance of ideas, enhance trust in e-commerce, shape perceptions, and increase willingness to online buying among targeted groups of consumers, especially at developing countries. However, managerial tools like that of hierarchical multiple regression, they showed significant variance of predicting consumers' behaviour (such as trust and willingness to online buying), thus better understood the theory and the practice of social media accordingly (Safia et al., 2019).

In the relevant literature key-aspects of live broadcast of social media and e-commerce can be approached by the means of internet marketing, e.g., online marketing toward brands' promotion, message delivery, market research, customer service, and channels of sale. Nowadays, e-commerce development is affecting the trading behavior of consumers and brands. Therefore, from a marketing viewpoint, social media should be developed in such a way to ensure the trustworthiness of brands and the consistency of attachment between brandname products and their buyers (Hsu, 2019). In approaching the e-commerce live broadcast uses through social media platform, it can be argued that such a live broadcast is strongly bounded on experience and trust. In particular, it was argued that differentiated trust can be explored through credibility of e-commerce, while customer relationships are substantially affecting by the trust and the flexibility of consumers' final purchase behavior. Besides, current researches disclosed that brand and social media are innovative in terms of ultimate sales trust, being also fundamental pillars of the live economy (Hsu, 2019).

\section{Methods and Data}

The three main related hypotheses of empirical study were created. The reasoning of all these three hypotheses' postulation and testing aimed at disclosing the motives of customers to select social media as the mainstream means to satisfy their needs for buying, socializing through digital platform, and keep a creative stance on social networks and e-commerce services' offered to them.

H1: The social media influence the e-commerce buying behaviours because of its capability to enhance customers' experience.

H2: Social media support the conveyance of ideas, shaping perceptions and modifying buying intentions of customers.

H3: There is a direct link between direct messaging entertainment for companies on social networks and a direct ordering feature that promotes sales on social networks.

One of the first steps in designing a quantitative research is to determine the general population. Thus, it is the whole population that is under the research. The general population of this research is all people living in Lithuania that use social networks.

Usually, the general populations of researches are very vast, hardly countable; thus, it is almost impossible to conduct a research with all units of the general population. Therefore, it is worth selecting such size of the general population, which, after conducting the research, would allow making foregrounded conclusions about the whole general population. The sample size has been determined by choosing $5 \%$ sampling error, $95 \%$ level of reliability and assuming that the size of the general population is $1,000,000$ units. During the quantitative research, it was aimed to interview 385 respondents in order to implement quantitative sample size requirements.

The questionnaire of the quantitative research has been prepared based on the marketing communication model for social media used by entertainment companies. The questionnaire includes closed type of questions, most of them are provided in Likert scale. It is aimed to test, i.e., confirm or deny the raised hypotheses, and at the same time, implement the aim and objectives of the research. The data that was obtained during the quantitative research has been processed by the IBM SPPS statistics program. The survey questions were provided in Tab. 2. 


\section{Tab. 2: Designing of survey questions}

\begin{tabular}{|c|c|c|}
\hline Question types & Questions & Justification of questions \\
\hline Filter questions & $\begin{array}{l}\text { Are you interested in different entertainment } \\
\text { activities (e.g., escape rooms, labyrinths, laser } \\
\text { games, children's playrooms, etc) for leisure? } \\
\text { Do you use social media (e.g., Facebook, } \\
\text { Instagram, Linkedln, etc)? }\end{array}$ & $\begin{array}{l}\text { The aim is to select } \\
\text { respondents that are suitable } \\
\text { for the research sample. }\end{array}$ \\
\hline Main questions & $\begin{array}{l}\text { Evaluate the aspects of social media used by the } \\
\text { entertainment companies, which are significant in } \\
\text { determining your decision to buy service(s)? } \\
\text { If there are other aspects of social media (not } \\
\text { mentioned in question } 8 \text { ), which are significant in } \\
\text { determining your decision to buy entertainment } \\
\text { company's service(s), please write them down: }\end{array}$ & $\begin{array}{l}\text { The aim is to find out what } \\
\text { social media functions } \\
\text { encourage respondents to } \\
\text { buy services. }\end{array}$ \\
\hline $\begin{array}{l}\text { Demographic } \\
\text { questions }\end{array}$ & $\begin{array}{l}\text { Your gender, age, social status and monthly } \\
\text { income: }\end{array}$ & $\begin{array}{l}\text { The aim is to determine } \\
\text { demographic indicators of } \\
\text { respondents. }\end{array}$ \\
\hline \multirow[t]{2}{*}{ Main questions } & $\begin{array}{l}\text { How much time do you spend on social media per } \\
\text { day on average? } \\
\text { What social networks that are used by the } \\
\text { entertainment companies encourage you to } \\
\text { buy services provided by the entertainment } \\
\text { organisation companies? }\end{array}$ & $\begin{array}{l}\text { The aim is to identify which } \\
\text { social networks are used } \\
\text { most by the respondents. }\end{array}$ \\
\hline & $\begin{array}{l}\text { Have you noticed the communication of } \\
\text { entertainment companies on social media? } \\
\text { Choose answers that most suit your behaviour } \\
\text { related to interaction with entertainment } \\
\text { companies on social media. } \\
\text { Check answers that best suit your opinion related } \\
\text { to being interested in entertainment companies on } \\
\text { social media. }\end{array}$ & $\begin{array}{l}\text { The aim is to find out what } \\
\text { social media functions } \\
\text { encourage respondents' } \\
\text { involvement in entertainment } \\
\text { companies. }\end{array}$ \\
\hline
\end{tabular}

The questions of the survey have been designed in such a way that they would be suitable in cyberspace and convenient, not requiring a lot of time to answer, for the respondents.

When performing a quantitative research, a questionnaire survey has been conducted. The questionnaire was posted online and was active from April 15 to May 15, 2020, i.e., the whole month. Aiming to get as many answers as possible, the survey link was sent personally via email and Facebook Messenger. In total, there were obtained 400 responses. This quantitative research aimed to reveal elements used by the entertainment companies on social media and how they promote sales.

\section{Results}

According to social-demographic characteristics of respondents, there can be observed that most of the respondents that participated in the research were female $78 \%$, and male composed only $22 \%$. According to age, more than half of respondents $(52 \%)$ were $26-36$ years old, and $33 \%$ were $18-25$ years old. Respondents that were older than 36 years composed only $14 \%$. According to the social status, most of the respondents $(56 \%)$ were workers, slightly less $(23 \%)$ working students and (17\%) students. The smallest number belonged to the unemployed $(3 \%)$ and pensioners $(0.3 \%)$. According to the monthly income, most of the respondents $(31 \%)$ declared that their income is between $801-1,200$ EUR; slightly less (22\%) 
stated that they earn 400-800 EUR, and 8.3\% of respondents were not willing to reveal their monthly income.

The first two questions of the survey were filter questions. The first question aimed to find out whether respondents are interested in different entertainment activities (e.g., escape rooms, labyrinths, laser games, children's playrooms) for leisure. This question received positive answers from $93.3 \%$ of respondents and negative from the rest, i.e., $6.7 \%$. The second questioned aimed to determine how many respondents use social media. Actually, $98.3 \%$ of respondents use social networks.

The third question aimed to identify how much time do respondents spend on social media per day on average. It has been determined that more than $65 \%$ of respondents use Facebook every day for 1 hour and more; only $2 \%$ of respondents were not using this network. Social network Instagram is used daily for 1 hour and more by $53 \%$ of respondents, and it was not used at all by $12 \%$ of respondents. Most of the respondents did not use social network Linkedln (42\%), and more than half of the respondents $(51 \%)$ used YouTube daily up to 2 hours. Distribution of respondents according to the time spent on social media is provided in Fig. 3.

Further on, the fourth question aimed to reveal where respondents usually look for online information when wanting to find out more about the services provided by the entertainment company.

Almost $70 \%$ of respondents never look for information about entertainment companies on social network Linkedin. Usually, they are searching for information on social network Facebook and the company's website. Almost $62 \%$ of respondents always look for information on entertainment companies on the search engine Google.

The fifth question aimed to reveal whether respondents notice communication of entertainment companies on social media (e.g., texts, photos, videos). Actually, $83.8 \%$ of respondents notice such type of communication, and the rest $16.2 \%$ of respondents do not notice it.

The questions six, seven and eight clarify what social media communication elements (e.g., content, regular communication, shopping function) encourage respondents to involve, show interest and purchase services of entertainment companies. In fact, $35.3 \%$ of respondents never share the content

\section{Fig. 3: Distribution according to time spent on social media}

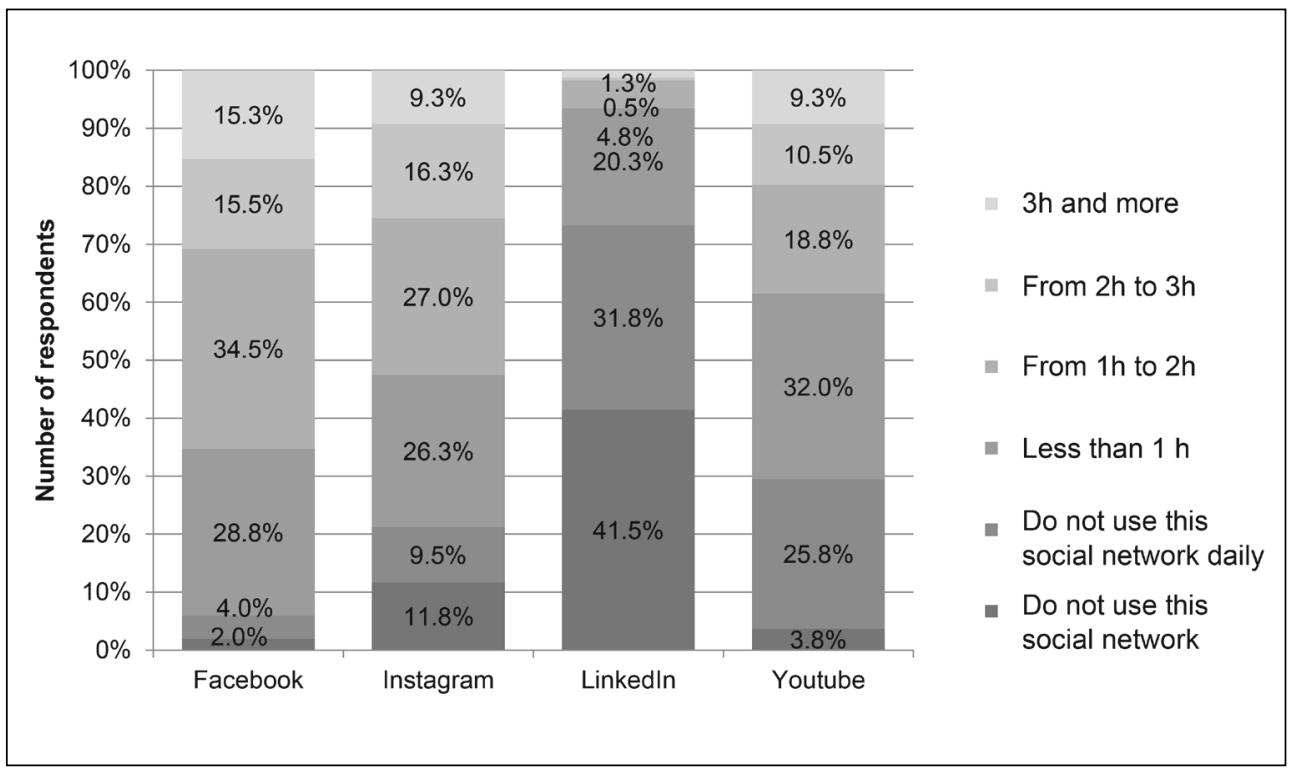


Tab. 3: Distribution of responses assessing engagement in communication

\begin{tabular}{l|c|c|c|c|c|c|c|c} 
& $\begin{array}{c}\text { Followed } \\
\text { accounts }\end{array}$ & Emoticons & Comments & $\begin{array}{c}\text { Games and } \\
\text { promotions }\end{array}$ & $\begin{array}{c}\text { Shared } \\
\text { content }\end{array}$ & Reviews & $\begin{array}{c}\text { Opened } \\
\text { links }\end{array}$ & Messages \\
\hline $\boldsymbol{N}$ Valid & 394 & 394 & 394 & 394 & 394 & 394 & 394 & 394 \\
\hline Missing & 0 & 0 & 0 & 0 & 0 & 0 & 0 & 0 \\
\hline Mean & 2.70 & 2.43 & 1.85 & 2.03 & 1.95 & 2.07 & 2.73 & 2.86 \\
\hline Median & 3.00 & 3.00 & 2.00 & 2.00 & 2.00 & 2.00 & 3.00 & 3.00 \\
\hline Std. dev. & 1.331 & 1.327 & 1.192 & 1.255 & 1.255 & 1.268 & 1.318 & 1.469 \\
\hline Minimum & 0 & 0 & 0 & 0 & 0 & 0 & 0 & 0 \\
\hline Maximum & 5 & 5 & 5 & 5 & 5 & 5 & 5 & 5 \\
\hline
\end{tabular}

Source: own

of entertainment companies that they like on their personal social media accounts. Moreover, $32.2 \%$ of respondents rarely comment on entertainment company's posts or other uploaded content; $42 \%$ sometimes open the posted links (for example, links to company's online website). Frequently, when wanting to reach entertainment company's representatives, $31.2 \%$ of respondents use the message function on social media.

Almost $60 \%$ of respondents agree that entertainment companies that engage in communication on social media remind and encourage interest in their activities. Moreover, $49 \%$ as well agree that entertainment companies that engage in communication on more than one social network are more attractive. In fact, $52.2 \%$ of respondents agree that they are interested in regular communication of entertainment companies (e.g., texts, photos, videos).

Respondents $(37 \%)$ agree that paid advertising (e.g., banners, active links, newsletters) posted by entertainment companies on social media, regular communication on social media $(60.3 \%)$, positive reviews and experiences of clients (53.8\%), content created by influencers $(47.5 \%)$, posted contests and promotions $(44.9 \%)$, content created by familiar people or place tags $(55.2 \%)$, order forms created by entertainment companies $(40.8 \%)$ encourage to buy service or services.

Further on, it was aimed to reveal the distribution of respondents, calculate arithmetic mean and standard deviation (Tab. 3).

As it could be seen in the Tab. 3, the standard deviation fluctuates from 1.192 to 1.469 . This means that the answers of respondents were quite different. It could be stated that different elements encourage respondents to engage in communication. The most common way for respondents to engage in communication is writing comments; the standard deviation is the lowest, i.e., 1.192. The calculated arithmetic mean reveal that messages (2.86), opened links (2.73) and regularly followed accounts (2.70) are the most important for respondents.

In the Tab. 4, the standard deviation fluctuates from 1.355 to 1.445 and is quite high. The opinions of respondents differentiated a lot. Moreover, in the provided calculations, it could be seen from the arithmetic mean that communication on social media (3.57) is important to the respondents as well as regular communication (3.47) and communication on more than one social network (3.37).

Tab. 5 provides the distribution of responses assessing decision to buy entertainment company's service or services.

As it could be seen in the Tab. 5, the standard deviation fluctuates from 1.328 to 1.475. This means that the responses of respondents were not unanimous. It should be noted that client reviews (3.62), regular communication of entertainment companies on social media (3.42) and content related to entertainment posted by familiar people (3.45) are important to the respondents when making a decision to buy service or services.

Further on in this study, aiming for accuracy in research, there was conducted data reliability calculation. The value of Cronbach's alpha coefficient should be more than 0.7 and as 


\section{Marketing and Trade}

\section{Tab. 4: Distribution of responses assessing interest in entertainment companies}

\begin{tabular}{l|c|c|c|c|c} 
& $\begin{array}{c}\text { Communication } \\
\text { on social media }\end{array}$ & $\begin{array}{c}\text { Communication } \\
\text { on more than one } \\
\text { social network }\end{array}$ & $\begin{array}{c}\text { Not interested if } \\
\text { a company is not } \\
\text { engaged in } \\
\text { commication } \\
\text { communication }\end{array}$ & $\begin{array}{c}\text { Not important } \\
\text { is engaged in com- } \\
\text { munication or not }\end{array}$ \\
\hline $\mathbf{N}$ Valid & 394 & 394 & 394 & 394 & 394 \\
\hline Missing & 0 & 0 & 0 & 0 & 0 \\
\hline Mean & 3.57 & 3.37 & 3.47 & 2.73 & 2.38 \\
\hline Median & 4.00 & 4.00 & 4.00 & 3.00 & 3.00 \\
\hline Std. dev. & 1.445 & 1.414 & 1.429 & 1.391 & 1.355 \\
\hline Minimum & 0 & 0 & 0 & 0 & 0 \\
\hline Maximum & 5 & 5 & 5 & 5 & 5 \\
\hline
\end{tabular}

Tab. 5: Distribution of responses assessing decision to buy services

\begin{tabular}{l|c|c|c|c|c|c|c} 
& $\begin{array}{c}\text { Paid } \\
\text { advertising }\end{array}$ & $\begin{array}{c}\text { Regular } \\
\text { communication }\end{array}$ & $\begin{array}{c}\text { Client } \\
\text { reviews }\end{array}$ & $\begin{array}{c}\text { Content } \\
\text { of influencers }\end{array}$ & $\begin{array}{c}\text { Contests and } \\
\text { promotions }\end{array}$ & $\begin{array}{c}\text { Content } \\
\text { of familiar } \\
\text { people }\end{array}$ & $\begin{array}{c}\text { Direct } \\
\text { order form }\end{array}$ \\
\hline N Valid & 394 & 394 & 394 & 394 & 394 & 394 & 394 \\
\hline Missing & 0 & 0 & 0 & 0 & 0 & 0 & 0 \\
\hline Mean & 2.85 & 3.42 & 3.62 & 3.13 & 2.99 & 3.45 & 3.07 \\
\hline Median & & & & & & & 1.455 \\
\hline Std. dev. & 1.328 & 1.380 & 1.475 & 1.428 & 0 & 0 & 0 \\
\hline Minimum & 0 & 0 & 0 & 0 & 5.427 \\
\hline Maximum & 5 & 5 & 5 & 5 & 5 & 5 & 5 \\
\hline
\end{tabular}

Tab. 6: Reliability coefficients of analysed responses

\begin{tabular}{l|c|c}
\multicolumn{1}{c|}{ Questionnaire } & Variables & Cronbach's alpha \\
\hline Engagement in communication & 8 & 0.935 \\
\hline Interest & 5 & 0.083 \\
\hline Decision to buy & 7 & 0.949 \\
\hline
\end{tabular}


close to 1 as possible, but not higher than 1 . It could be seen in Tab. 6 that all questions are reliable. Cronbach's alpha is higher than 0.7.

The quantitative research aimed to reveal if there exists a relation between elements of social media used for sales promotion and users' engagement in communication; therefore, the correlation analysis has been chosen. It has been determined to employ Spearman correlation in order to calculate ordinal data.

First, separate questions have been grouped into 2 blocks of 4 .

1. Dimension of users' engagement in communication: followed accounts on social media, participation in promotions and games, payed advertising, use of message function.

2. Dimension of entertainment companies' sales promotion: regular communication, content created by influencers, content created by users, direct order form.

The values of these correlation coefficients are distinguished: from 0 to 0.2 is a very weak correlation (no relationship); from 0.2 to 0.4 is a week correlation (week relationship); from 0.4 to 0.7 is an average correlation (average relationship); from 0.7 to 0.9 is a strong correlation (strong relationship); more than 0.9 is a very strong correlation.

The results of Spearman correlation analysis are provided in the Tab. 7 .

Thus, it could be seen from the conducted Spearman's correlation analysis that there exist week and average relationships between users' engagement in communication and entertainment companies' sales promotion dimensions. There is an average relationship (0.560) between users' followed accounts on social media and entertainment companies' dimension. There is a week relationship (0.445) between users' participation in promotions and games and the content created by the influencers. There is a week relationship $(0.438)$ between content created by users and paid advertising. There is a week relationship

\section{Tab. 7: Results of correlation analysis}

\section{Spearman's correlation analysis 1}

\begin{tabular}{l|l|l|l}
\hline \multirow{4}{*}{ Spearman's rho } & \multirow{3}{*}{$\begin{array}{l}\text { Followed accounts } \\
\text { on social media }\end{array}$} & Correlation coefficient & Regular communication \\
\cline { 3 - 4 } & & Sig. (2-tailed) & $0.560^{* *}$ \\
\cline { 3 - 4 } & & $\mathrm{N}$ & 3900 \\
\hline
\end{tabular}

Spearman's correlation analysis 2

\begin{tabular}{l|l|l|l}
\hline \multirow{4}{*}{ Spearman's rho } & \multirow{2}{*}{$\begin{array}{l}\text { Participation in } \\
\text { promotions and } \\
\text { games }\end{array}$} & Correlation coefficient & Content created by influencers \\
\cline { 3 - 4 } & & Sig. (2-tailed) & $0.445^{\star *}$ \\
\cline { 3 - 4 } & $\mathrm{N}$ & 0.00 \\
\hline
\end{tabular}

\section{Spearman's correlation analysis 3}

\begin{tabular}{l|l|l|l}
\hline \multirow{4}{*}{ Spearman's rho } & \multirow{4}{*}{$\begin{array}{l}\text { Content created by } \\
\text { users }\end{array}$} & & Paid advertising \\
\cline { 3 - 4 } & & Correlation coefficient & $0.438^{* *}$ \\
\cline { 3 - 4 } & Sig. (2-tailed) & 0.00 \\
\cline { 3 - 4 } & $\mathrm{N}$ & 394
\end{tabular}

Spearman's correlation analysis 4

\begin{tabular}{l|l|l|l}
\hline \multirow{4}{*}{ Spearman's rho } & \multirow{4}{*}{ Direct order form } & Message function \\
\cline { 3 - 4 } & & Correlation coefficient & $0.472^{\star \star}$ \\
\cline { 3 - 4 } & Sig. (2-tailed) & 0.00 \\
\cline { 3 - 4 } & $\mathrm{N}$ & 394 \\
\hline
\end{tabular}


(0.472) between direct order form and message function.

\section{Discussion}

\subsection{Theoretical Contributions and Implications}

The theoretical contributions disclosed the linkages between social media and internet marketing. The marketing strategy of promotion by using multimedia format can be linked with a range of problems and advantages of the multimedia products. It is important to determine those basic requirements for the creation of a multimedia format to reflect on how information can be exchanged between inside multimedia resource and the resource as a whole with the external information environment. It is suggested that monitoring of hashtags should reveal the popularity and the interest among users of social networks Instagram and Twitter multimedia format as a book trailer (Bilushchak et al., 2020).

Internet marketing adoption in emerging industrial markets across several internetbased technologies (such as social media platforms, static and transactional websites) has been rarely investigated, despite its importance and potential. It was observed that organizations are using the internet as a oneway communication through static websites, while the development of internet marketing can be positively related to perception of compatibility, organizational innovativeness, competitor and customer pressure. Therefore, it is imperative need decision-makers to identify paths of wider involvement in internet marketing and to enhance awareness through educating industrial organizations, as SMEs, about internet-offered opportunities (Shaltoni, 2017).

In this research context, online advertising is also experiencing severe competition, while changes are necessitated for the transition from traditionally printed advertising media to digital ones, e.g. email, search engineering, and social media outlets, in order to promote their activities. Besides, the growing convergence of digital technologies makes it complex to distinguish among different forms of online marketing. It is also notable the technologically overlapping activities as these are mostly occurring at online marketing and advertising outlets, thus, it is crucial researches to determine the available forms of Internet (online, in general) marketing offered: technological trends, practices, and academic research especially in the domains of Web 2.0 and social media technologies (Ayanso et al., 2014).

Scientific literature on social media and Internet management represented the main aspects to be further investigated at resolving practical implications in practice. In such a particular study on social media and Internet coordination, contacting emergency respondents depend critically on largescale natural disasters affecting citizens to obtain and disseminate information while communicating with first respondents, but also for peoples' services as volunteers who seek helping each other, complementing the role of first respondents, enabling them of tweeting disaster-related information whenever needed, thus, helping social media to be feasibly supportive in disaster management (Jahanian et al., 2018).

Notable uses of social media have been also approached among industry and government organisations through Customer Relationship Management (CRM) activities. Such activities can assess organisations' effectiveness, since they involve communication with customers regarding services/products offered and distilling customer opinions (Wan et al., 2015). In this study social media and CRM can be valued in terms of a VIZIE system. The CRMVIZIE functionality can implement such data analysis conditions in achieving real-time response at an internet-wide big social data prospected (Wan et al., 2015).

In contemporary managerial conditions among pharmaceutical companies changes of selling over-the-counter (OTC) medicines has been proposed due to increased pressure on sales margins. In particular, OTC drug market could adopt a customer-friendly managerial strategy through utilizing social media. In such a new-age managerial environment digital marketing should enrich Kotler's 4 P's of marketing (product, price, place and promotion), showing conceptual linkages between anchoring theory, data analysis, and theoretical accrued returns, and offering a pluralistic understanding of how Internet and social media operations should drive the management of pharmaceutical industries in practice (Roblek, 2015).

In another application SMEs to the social media are proven capable of boosting productivity, fostering innovation, and gaining 
fame (Tsekouropoulos et al., 2014) where SMEs can be organized in the food and beverage sector, unveiling that the whole food chain should be oriented to the well being of consumers and to the sustainability of the food sector by using Internet-based applications (Tsekouropoulos et al., 2014). In a similar study social media are influencing behavioral patterns of millions of users by making fashion, entertainment, and eating proposals, thus, positively impacting on the performance and on the profitability of food and beverage businesses (Binsawad, 2020).

\subsection{Implications for Practice}

Social media analytics tools are comprising a unique information source for business intelligence and assessment of digital platforms, thus, in the relevant literature two social media analytics tools, Website Grader and LikeAlyzer, they were selected to evaluate the wine industry in Greece and Germany (Costopoulou et al., 2019). These analytics tools were proven effective to value corporate websites and Facebook pages, improving their social media utility, while recommendations for further improvement in using these social media were also given (Costopoulou et al., 2019).

The implementation of social media enables modern organizations to serve suppliers and customers, increase business performance, strengthen competitiveness, and achieve continuous success in today entrepreneurship of marketing, communication management, tourism and health care industries, as well as multifaceted platform-formed applications of business interest. Social media can enhance organizational performance and reach strategic goals in the today and future of social media era (Kasemsap, 2016).

In the relevant literature Social Media Apps (SMA) are proven capable to facilitate individual communications, especially between companies' facilitation with their customers. Besides, SMA have been sporadically utilized in the Business-to-Business context. Therefore, a Media Synchronicity Theory (MST) has modeled to empirically investigate the relationship between the main capabilities of SMA: transmission velocity, parallelism, symbol sets, rehearsability, reprocessability, and B2B communication and business performance. A relevant face-to-face survey among senior managers/owners of SME revealed that the missing SMA capability of information security and control, could support the proposed model and it may be an important addition to MST (Wang et al., 2016).

Social media has restructured the paths of which availability of information can reached from companies to future customers, thus, small business leadership should be driven to use social media marketing in supporting businesses to survive in the a competitive marketplace and economically liquidity era. To this end, critical considerations of social media effectiveness should find ways of differentiating businesses from their competitors whilst incorporating social media into their marketing activities (Taueja \& Toombs, 2014). Social media in association with E-commerce and brand was addressed by numerous studies which findings are summarized below.

Through a scientometrics analysis it was investigated the status and the evolution of the scientific studies on the effect of social networks on e-commerce. Scientometrics can support researchers to determine those highly influential countries, institutions, and keyareas' selection for scientific research, enabling researchers to better understand those keydeterminants between social networks utility on e-commerce (Javid et al., 2019).

Social media influencers are conveying their opinion regarding products and brands through social media postings. These influencers might add a disclosure in non-sponsored product posts that highlight their impartiality. However, this information ought to affect how consumers respond to the post. In emphasizing impartiality of influencer product posts toward consumers' response, a factorial design included the following disclosure types: impartial vs. explicit sponsorship vs. no disclosure. Besides, it is noteworthy how disclosure- and landing pagetypes: e-commerce product page vs. start page, from brand hyperlinks in the influencer post, they are interacting to form consumer brand attitudes and purchase intentions. Impartiality product posts are less likely to be perceived as advertising, comparing to sponsored product posts or posts without sponsorship information, thus, generating message credibility (Stubb \& Colliander, 2019).

Another critical aspect of analysis is the influential role of social media marketing activities on customer loyalty. In such an approach it was examined the impact of perceived social media 
marketing activities (SMMAs) on customer loyalty via customer equity drivers (CEDs) in an e-commerce context. SMMAs of e-commerce are significantly and positively influencing all the drivers of customer equity (CEDs). Moreover, the CEDs of e-commerce sustain a significant and positive influence on customer loyalty toward the e-commerce sites. In general, the introduction of a stimulus-organism-response model can support (even at a theoretical basis) the linkages among perceived SMMAs of e-commerce to customers' loyalty via CEDs (Yadav \& Rahman, 2018).

In the literature production regarding the association of electronic word of mouth (eWOM) with e-commerce websites (EC-eWOM) or social media (SM-eWOM) has been sporadically studied, therefore little is known about those processes' adopted when consumers are jointly presented EC-eWOM and SM-eWOM. In response to this underdeveloped research field, this problem was approached by adopting an interactive process. This process determined different effects of consumers' cognitive level of adoption and degree of involvement, especially from the perspective of cognitive cost theory. In particular, it was argued that EC-eWOM's usefulness and credibility influenced in a positive manner the adoption of EC-eWOM, but they negatively valued that of SM-eWOM. Moreover, EC-eWOM adoption was negatively impacting on SM-eWOM adoption; while this EC-eWOM adoption also mediated the usefulness and the credibility of a SM-eWOM adoption (Yan et al., 2016).

\subsection{Limitations and Future Research Directions}

Based on the empirical study it was shown that the elements referring to promotion of sales increase; brand strengthening, maintaining connections with present and potential company's clients that are used by the entertainment companies on social media, are supporting companies to accomplish a combination of tactile and intactile benefits. In particular, utmost importance tactile benefits of entertainment companies are the promotion of sales with users' engagement, while the main intactile benefits are oriented at promoting sales of goods and services, increase recognition, enhance visibility and envisage communication with a wider group of social media fans, as potential clients in real time online.
Critical implications should be addressed while balancing out the cost effectiveness between these tactile and intactile benefits, or otherwise postulated, between the technoeconomic and societal dimensions, respectively. Other research limitations are associated with the fact that the three hypotheses have been tested in a specific sampling population at a specific timeframe, offering a "static" valuation of a rather rigorously evolving topic, in terms of:

1. Technologically and societal changing and digitalized world, among the Generations $X$, $\mathrm{Y}$, and $\mathrm{Z}$;

2. Different interests and customers' behaviours among men and women;

3. Leapfrog technologies prevailing especially among developing economies worldwide.

Therefore, future research directions should be focused on strengthening and enhancing the accessibility and regular communication of entertainment companies on social media, thus positively effecting on wide spectrum of benefits: sales increase, development of prestigious brand naming, building up familiar internet platforms and digital interfaces (that are aspects of internet marketing) between entertainment products' promotion and active engagement of users to contemporary digital accounts. From a methodological viewpoint, hypotheses enrichment and adaptation to future sociocultural conditions have to be drawn, possibly accompanied by follow-up studies at a future time, accordingly (Kyriakopoulos, 2011, 2012). The very end of such a research approach should be the determination of, commonly space-specific and chronologically evolutionary advancements towards the achievement of delighted customers, no merely satisfied customers, through consistently appreciating social networks and social commerce.

\section{Conclusions}

After literature review on employing social media for sales promotion, it has been determined that there is no universal classification or characteristics of social media that would be commonly agreed by the scientists. The most commonly distinguished media include communication and search for connections, content creation and sharing, entertainment and, of course, offering goods and services.

Most of social media overlap, i.e., have more than one characteristic, aim or purpose. 
It should be noted that interaction, userfriendliness, openness, freedom and real time unite all of them. When starting to discuss sales promotion of a company on social media, the concept of social commerce becomes inevitable. Thus, a well-thought out strategy, confidence that can be created in different ways (original, unique and qualitative content created by the influencers, regular communication) as well as interaction are important.

After having reviewed the best marketing decisions of small and medium-sized companies and tourism industry, it could be stated that most of them could be applied to entertainment organisation companies. The studies have found that effective social commerce includes the supply of goods and services that is integrated in the common communication, but there is a possibility to buy goods and services here and now by marking them in photos with special tags and redirecting to chat window.

The following elements were found to be crucial for gaining competitive advantages in the market: complementarity, innovations, marketing and learning. It is useful to rely on e-marketing complex: advertising, sales promotion, personal sales, direct sales and public relations, choosing a suitable communication channel for each of them online. Comprehensive digital content and enabled user reviews that perform online WOM role are important as well as event marketing, which could become a successful tool in tourism, entertainment and leisure companies creating added emotional value.

After having analysed empirical studies that have been conducted over the past decade in different contexts, it could be stated that authors tend to analyse social media together with other online marketing tools. When using these tools, usually, they 1) promote sales increase, 2) strengthen brand, 3) help to make and maintain connections with present and potential company's clients. It should be stressed that one as well as several in a complex used online marketing tools can have an impact.

After having conducted a quantitative case study on elements used by the entertainment companies on social media to promote sales, a conclusion could be made that week and average relationships that have been revealed during Spearman's correlation analysis are statistically significant. Thus, all elements that are used by the entertainment companies on social media help to promote sales with users' engagement. Regular communication of entertainment companies on social media has a positive impact on sales, because users tend to follow such type of accounts actively.

The study highlighted the main elements to be applied by the entertainment companies on social media, such as regular communication, content created by influencers, content created by users, direct order form, have a positive impact on sales promotion. Companies are advised to communicate regularly: it is the strongest approved relationship to sales promotion.

\section{References}

Abed, S. S., Dwivedi, Y. K., \& Williams, M. D. (2015). SMEs' adoption of e-commerce using social media in a Saudi Arabian context: A systematic literature review. International Journal of Business Information Systems, 19(2), 159-179. https://doi.org/10.1504/ IJBIS.2015.069429

Abud, Y. A. (2018). What is the difference between digital and online marketing? White Shark Media. Retrieved from https://www. whitesharkmedia.com/blog/digital-marketing/ digital-vs-online-marketing/

Ahmed, R. R., Hussain, S., Pahi, M. H., Usas, A., \& Jasinskas, E. (2019). Social Media Handling and Extended Technology Acceptance Model (ETAM): Evidence from Sem-Based Multivariate Approach. Transformations in Business \& Economics, 18(48), 246-271.

Ajina, A. S. (2019). The perceived value of social media marketing: an empirical study of online word-of-mouth in Saudi Arabian context. Entrepreneurship and Sustainability, 6(3), 1312-1327. https://doi.org/10.9770/ jesi.2019.6.3(32)

Akhmetova, Z. B., Turginbayeva, A. N., \& Shurenov, N. B. (2018). Development of Internet Marketing in the EAEU Countries. RUDN Journal of Economics, 26(2), 175-185. https://doi.org/10.22363/2313-2329-2018-26-2175-185

Ayanso, A., Lertwachara, K., \& Mokaya, B. (2014). Marketing meets social media: Classification and evolution of internet marketing. Marketing and Consumer Behavior: Concepts, Methodologies, Tools, and Applications, 1-4, 473-500. https://doi. org/10.4018/978-1-4666-7357-1.ch021 
Bilushchak, T., Radkovets, O., \& Syerov, Y. (2020). Internet marketing strategy promotion of a book in social media. In Proceedings of the 2nd International Workshop on Control, Optimisation and Analytical Processing of Social Networks (COAPSN 2020) (pp. 260272). Lviv, Ukraine.

Binsawad, M. (2020). Social media efficiency towards restaurant business: A comparison between social media profiles (case study in Saudi Arabia). Multimedia Tools and Applications, 79(3), 31389-31399. https:// doi.org/10.1007/s11042-020-09620-z

Boyd, M. D., \& Ellison, N. B. (2008). Social Network Sites: Definition, History, and Scholarship. Journal of Computer-Mediated Communication, 13(1), 210-230. https://doi. org/10.1111/j.1083-6101.2007.00393.x

Costopoulou, C., Ntaliani, M., \& Ntalianis, F. (2019). An analysis of social media usage in winery businesses. Advances in Science, Technology and Engineering Systems, 4(4), 380-387. https://doi.org/10.25046/aj040446

Dabija, D-C., Bejan, B-M., \& Dinu, V. (2019). How Sustainability Oriented is Generation $Z$ in Retail? A Literature Review. Transformations in Business \& Economics, 18(2), 140-155.

Duffett, R. G., Edu, T., Negricea, I. C., \& Zaharia, R. M. (2020). Modelling the Effect of YouTube as an Advertising Medium on Converting Intention-To-Purchase into Purchase. Transformations in Business \& Economics, 19(1), 112-132.

Evans, D. (2008). Social Media Marketing: An Hour a Day. Hoboken, NJ: Wiley Publishing.

Gavurova, B., Bacik, R., Fedorko, R., \& Nastisin, L. (2018). The Customer's Brand Experience in the Light of Selected Performance Indicators in the Social Media Environment. Journal of Competitiveness, 10(2), 72-84. https://doi.org/10.7441/joc.2018.02.05

Han, H., Xu, H., \& Chen, H. (2018). Social commerce: A systematic review and data synthesis. Electronic Commerce Research and Applications, 30, 38-50. https://doi. org/10.1016/j.elerap.2018.05.005

Hudák, M., Kianičková, E., \& Madleňák, R. (2017). The Importance of E-mail Marketing in E-commerce. Procedia Engineering, 192, 342-347. https://doi.org/10.1016/j. proeng.2017.06.059

Hsu, K. K. (2019). Discussion on the live broadcast of social media and e-commerce. In Proceedings of the 19th International
Conference on Electronic Business (pp. 178185). ICEB, Newcastle Upon Tyne, United Kingdom, December 8-12.

Jahanian, M., Xing, Y., Chen, J., Ramakrishnan, K. K., Seferoglu, H., \& Yuksel, M. (2018). The Evolving Nature of Disaster Management in the Internet and Social Media Era. In 2018 IEEE International Symposium on Local and Metropolitan Area Networks (LANMAN) (pp. 79-84). https://doi.org/10.1109/ LANMAN.2018.8475116

Javid, E. T., Nazari, M., \& Ghaeli, M. R. (2019). Social media and e-commerce: A scientometrics analysis. International Journal of Data and Network Science, 3(3), 269-290. https://doi.org/10.5267/j.ijdns.2019.2.001

Kasemsap, K. (2016). Mastering social media in the modern business world. In $\mathrm{N}$. R. Rao (Ed.), Social Media Listening and Monitoring for Business Applications (pp. 18-44). Hershey, PA: IGI Global. https://doi. org/10.4018/978-1-5225-0846-5.ch002

Keenan, A., \& Shiri, A. (2009). Sociability and social interaction on social networking websites. Library Review, 58(6), 438-450. https://doi.org/10.1108/00242530910969794

Knoll, J. (2016). Advertising in social media: a review of empirical evidence. International Journal of Advertising, 35(2), 266-300. https:// doi.org/10.1080/02650487.2015.1021898

Kwahk, K.-Y., \& Ge, X. (2012). The Effects of Social Media on E-Commerce: A Perspective of Social Impact Theory. In Proceedings of the 45th Hawaii International Conference on System Sciences (pp. 1814-1823). Maui, HI, USA. https://doi.org/10.1109/HICSS.2012.564

Kyriakopoulos, G. (2011). Project Management (PM) Prosperity: A Second Half of the 20th Century Literature Review. Journal of Management and Sustainability, 1(1), 64-81. https://doi.org/10.5539/jms.v1n1p64

Kyriakopoulos, G. (2012). Half a century of management by objectives (MBO): A review. African Journal of Business Management, 6(5), 1772-1786. https://doi.org/10.5897/ AJBM10.1585

Mróz-Gorgoń, B., \& Peszko, K., (2016). Marketing analysis of social media - definition considerations. European Journal of Service Management, 20(4), 33-40. https://doi. org/10.18276/ejsm.2016.20-04

Onete, C.-B., Vargas, V. M., \& Chita, S. D. (2020). Study on the Implications of Personal Data Exposure on the Social Media Platforms. 
Transformations in Business \& Economics, 19(2), 243-258.

Pardo, A. (2013). Digital Hollywood: How Internet and Social Media Are Changing the Movie Business. In M. Friedrichsen, \& W. Mühl-Benninghaus (Eds.), Handbook of Social Media Management: Value Chain and Business Models in Changing Media Markets (pp. 327347). Berlin, Heidelberg: Springer. https://doi. org/10.1007/978-3-642-28897-5_19

Pavlovaite, U., \& Griesiene, I. (2019). Development of an Art Platform in Terms of Relationship Marketing: A Biennial Case. Transformations in Business \& Economics, 18(2), 259-278.

Roblek, V. (2015). Impact of internet and social media on organisational change of OTC medicines marketing management. International Journal of Electronic Marketing and Retailing, 6(3), 239-258. https://doi. org/10.1504/IJEMR.2015.070806

Safia, A., Chai, J., Frimpong, A. N. K., \& Akram, U. (2019). The impact of social media characteristics on e-commerce use behaviour among youth in developing countries. International Journal of Information Systems and Change Management, 11(2), 188-207. https://doi.org/10.1504/IJISCM.2019.104629

Shaltoni, A. M. (2017). From websites to social media: exploring the adoption of internet marketing in emerging industrial markets. Journal of Business and Industrial Marketing, 32(7), 1009-1019. https://doi.org/10.1108/ JBIM-06-2016-0122

Stewart, D. W. (2009). Marketing accountability: Linking marketing actions to financial results. Journal of Business Research, 62(6), 636-643. https://doi.org/10.1016/j. jbusres.2008.02.005

Stoian, O., Polozova, T., Didenko, E., Storozhenko, O., \& Moskvichova, O. (2018). Strategies of interaction with a consumer within the marketing product policy. Entrepreneurship and Sustainability Issues, 6(2), 1018-1027. http://doi.org/10.9770/jesi.2018.6.2(36)

Stubb, C., \& Colliander, J. (2019). "This is not sponsored content" - The effects of impartiality disclosure and e-commerce landing pages on consumer responses to social media influencer posts. Computers in Human Behavior, 98, 210222. https://doi.org/10.1016/j.chb.2019.04.024

Taueja, S., \& Toombs, L. (2014). Putting a face on small businesses: Visibility, viability, and sustainability the impact of social media on small business marketing. Academy of Marketing Studies Journal, 18(1), 249-260.

Tsekouropoulos, G., Vatis, S.E., Andreopoulou, Z., Katsonis, N., \& Papaioannou, E. (2014). The aspects of internet-based management, marketing, consumer's purchasing behavior and social media towards food sustainability. Rivista di Studi sulla Sostenibilita, 2, 207-222. https://doi. org/10.3280/RISS2014-002013

Tuten, T. L., \& Solomon, M. R. (2018). Social Media Marketing. Thousand Oaks, CA: SAGE Publications.

Wan, S., Paris, C., \& Georgakopoulos, D. (2015). Social Media Data Aggregation and Mining for Internet-Scale Customer Relationship Management. In 2015 IEEE $16^{\text {th }}$ International Conference on Information Reuse and Integration (IRI 2015) (pp. 39-48). San Francisco, CA, USA. http://doi.org/10.1109/ IRI.2015.17

Wang, W. Y. C., Pauleen, D. J., \& Zhang, T. (2016). How social media applications affect B2B communication and improve business performance in SMEs. Industrial Marketing Management, 54, 4-14. http://doi.org/10.1016/j. indmarman.2015.12.004

Xie, B., Huang, M., \& Watkins, I. (2012). Technology and Retirement Life: A Systematic Review of the Literature on Older Adults and Social Media. In M. Wang (Ed.), The Oxford Handbook of Retirement (pp. 493-509). Oxford, NY: Oxford University Press.

Yadav, M., \& Rahman, Z. (2018). The influence of social media marketing activities on customer loyalty: A study of e-commerce industry. Benchmarking: An International Journal, 25(9), 3882-3905. http://doi. org/10.1108/BIJ-05-2017-0092

Yaman, Z. (2018). The Effect of Word of Mouth Marketing on the Purchase Behavior via Brand Image and Perceived Quality. Montenegrin Journal of Economics, 14(2), 175-182. http://doi.org/10.14254/18005845/2018.14-2.12

Yan, Q., Wu, S., Wang, L., Wu, P., Chen, H., \& Wei, G. (2016). E-WOM from e-commerce websites and social media: Which will consumers adopt? Electronic Commerce Research and Applications, 17, 62-73. http:// doi.org/10.1016/j.elerap.2016.03.004

Yu, X., \& Yuan, C. (2019). How consumers' brand experience in social media can improve brand perception and customer equity. Asia 
Pacific Journal of Marketing and Logistics, 31(5), 1233-1251. http://doi.org/10.1108/ APJML-01-2018-0034

Zhang, P., Zhou, L., \& Zimmermann, H.D. (2013). Advances in Social Commerce Research: GuestEditors'Introduction. Electronic Commerce Research and Applications, 12(4),
221-223. Retrieved from https://papers.ssrn. com/sol3/papers.cfm?abstract_id=2352569

Zhang, S., Li, F., \& Xiao, J. J. (2020). Internet penetration and consumption inequality in China. International Journal Consumer Studies, 44(5), 407-422. https://doi.org/10.1111/ ijcs. 12575 